\title{
Developing of a ventilation system for residential houses with solar air heater
}

\author{
Zohrab Melikyan*, Siranush Egnatosyan and Naira Egnatosyan \\ National University Architecture and Construction of Armenia, HVAC Chair, 0009 Yerevan, \\ Armenia
}

\begin{abstract}
Ventilation of buildings in winter period, especially in cold climatic conditions, requires rather big quantity of heat for preheating the ventilation fresh air. Consequently, an average low-income family pays a tangible cost for ventilation of apartments. To provide low cost ventilation of houses it is becoming attractive the use of solar energy for preheating the outside fresh air, before its supplying into the house. For this purpose, cheap solar air heaters are needed. To solve this problem a simple and cheap construction of solar air heater was developed, which is the main part of the ventilation system. The system consists of air heating solar collectors, installed on the roof of the house, warm air distribution ductwork, internal air circulation ducts and air-circulating fan. In summer period, the system is used only during nighttime period for circulating outside colder air through the internal space of the house. Such operation allows cooling internal air and as well the constructions of the house. As a result, the house accumulates nighttime natural cold for using it at daytime cooling purposes. Presentation includes the scheme, explanation of operation and method for design of suggested ventilation system. Analysis proved the energy efficiency and cost effectiveness of the new system.
\end{abstract}

\section{Introduction}

The ventilation of houses in winter period needs initial heating of outside fresh air up to the required inside temperature of a house. The preliminary heating of fresh air demands rather big consumption of energy and fuel. For this reason before supplying of ventilation fresh air into the house, it should be initially heated in special "hot water to air" type heat exchangers.

According to the construction norms and rules the quantity of ventilation outside fresh air depends on sizes of the house and number of habitants. Each habitant of a standard residential house should be provided with $g_{\text {vent. }}=20 \mathrm{~m}^{3} / \mathrm{h}$ or $g_{\text {vent }}=0,0056 \mathrm{~m}^{3} / \mathrm{s}$ of fresh air. For example a standard family house, specified for 10 family with 5 person each or totally for 50 habitant of the house requires a quantity of ventilation air that can be calculated by the following equation:

$$
G_{\text {vent. }}=g_{\text {vent }} \cdot n_{\text {hab }} \cdot \rho_{\text {air }} \mathrm{kg} / \mathrm{s} \text {. }
$$

\footnotetext{
* Corresponding author: zohrabmelikyan@yahoo.com
} 
where $: g_{\text {vent. }}=0.0056 \mathrm{~m}^{3} / \mathrm{s}$ standard norm of fresh air for 1 habitant per second,

$n_{\text {hab. }}=250$ habit. - number of habitants of the house,

$\rho_{\text {air }}=1.25 \mathrm{~kg} / \mathrm{m}^{3}-$ density of air.

Substitute of above values in (1) and making calculations will determine the quantity of ventilation air to be supplied into the average residential building per second:

$$
G_{\text {vent. }}=0.0056 \cdot 250 \cdot 1.25=1.75 \mathrm{~kg} / \mathrm{s}
$$

For heating the ventilation fresh air from outside $t_{\text {out }}=-19^{\circ} \mathrm{C}$ to inside $t_{\text {ins }}=18{ }^{\circ} \mathrm{C}$ temperature the heat consumption $Q_{\text {vent }}$ will make a value which is calculated by the following equation:

$$
Q_{\text {vent }}=G_{\text {vent }} c_{\text {air }}\left(t_{\text {in }}-t_{\text {out }}\right)
$$

where: $c_{\text {air }}=1.04 \mathrm{~kJ} /\left(\mathrm{kg}^{\circ} \mathrm{K}\right)$ - specific heat of air, $t_{\text {in }}=18^{\circ} \mathrm{C}, t_{\text {out }}=-19^{\circ} \mathrm{C}$ - inside and outside air design temperatures.

Substitute of data in (2) and making appropriate calculations will obtain the quantity of heat $Q_{\text {vent }}$, needed for preheating of ventilation fresh air:

$$
Q_{\text {vent }}=1.75 \cdot 1.04(18-(-19)=67.34 \mathrm{~kW}
$$

For supplying of $67.34 \mathrm{~kW}$ of thermal energy from gas heater will be needed fuel gas $V_{\text {gas }}$ the quantity of which is determined by the following formula:

$$
V_{\text {gas }}=\frac{Q_{\text {vent }}}{\eta_{b} Q_{f}}, \mathrm{~m}^{3} / \mathrm{s}
$$

where: $Q_{v e n t}-$ quantity of heat for heating ventilation outside fresh air, $\mathrm{kWh}$

$\eta_{b}=0.8$ - energy efficiency of heating boiler,

$Q_{f}=34700 \mathrm{~kJ} / \mathrm{m}^{3}-$ heating value of natural gas fuel.

Substitute of obtained values in (3) and making calculations will determine the fuel (gas) consumption $V_{\text {gas }}$, in case of use of a gas boiler makes:

$$
V_{\text {gas }}=\frac{67.34}{0,8 \cdot 34700}=0.0024 \mathrm{~m}^{3} / \mathrm{s} \text { or } 8.64 \mathrm{~m}^{3} / \mathrm{h}
$$

The seasonal gas consumption will be:

$$
B_{\text {gas.seas }}=V_{\text {gas }} \cdot m \cdot Z_{\text {seas }}=8.64 \cdot 0.5 \cdot 5500=23760 \mathrm{~m}^{3} / \text { seas. }
$$

where : $m=0.5$ - gas consumption seasonal averaging coefficient season, $Z_{\text {seas }}=5500 \mathrm{~h}$ - duration of winter season.

As in Armenia the cost of $1 \mathrm{~m}^{3}$ of gas makes approximately $\$ 0.32$, the quantity of natural gas, consumed only for preheating of the ventilation air, will cost at least $\$ 7603$ per heating season, which is a significant amount for low income families. The consumption of gas fuel can significantly be reduced, if the fuel gas is replaced by solar energy.

\section{Method for calculation and design of void type air solar heater}

The existing types of air solar heaters [1], are rather complicated and has low efficiency. Besides, the method for its design is rather rough. For providing efficient solar heating simple and cheap air heaters should be developed and used. For this reason, the authors of 
this presentation have developed a new simplified and cheap construction of solar air heater, which is presented in fig. 1 .

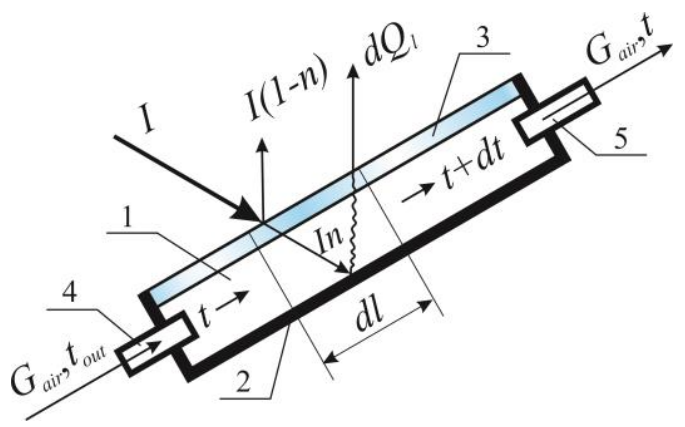

Fig.1. New simplified and cheap construction of solar air heater

The suggested solar air heater represents itself a rectangular metallic box made of steel angle bars. The upside frame is covered by $2 \mathrm{~mm}$ thick glass. The side walls and the bottom of the box are made of $1.5 \mathrm{~mm}$ thick iron sheets. In the inside space of the box nothing is located, it is empty. For this reason, the suggested solar air heater is called void type solar air heater. The void type solar air heater operates in the following way: solar rays penetrate through upside glass cover (3) into the rectangular dark colored box (1) and are absorbed by black internal surface, which is insulated (2) from outside. Outside air enters into the box through inlet duct (4) where contacts to internal hot surface of the box and is heated. The hot air exits from the hot box by the opposite side duct (5) and passes to the ventilation system of the house.

The goal of calculation of the suggested heater is determining the width $(b, \mathrm{~m})$, length $(l, \mathrm{~m})$ and height $(\delta, \mathrm{m})$ of the hot box for providing required temperature of the air $t_{v . h},{ }^{\circ} \mathrm{C}$ under given outside temperatures $t_{\text {out }},{ }^{\circ} \mathrm{C}$ and intensity $I, \mathrm{~W} / \mathrm{m}^{2}$ of solar radiation.

For describing the mentioned correlation a method of calculation and design has been developed, which is based on the following differential equation of energy balance:

$$
\left[I \cdot n-K\left(t-t_{\text {out }}\right)\right] d F=G_{v} c_{\text {air }} d t \quad \text { or } \quad\left[\left(I \cdot n+K t_{\text {out }}\right)-K t\right] d F=G_{v} c_{\text {air }} d t
$$

where: $I$ - daily average intensity of solar radiation falling on the solar collector mounted on southern facing surface of the roof and inclined $30^{\circ}$ relative to horizontal surface, $\mathrm{W} / \mathrm{m}^{2}$,

$n$ - rate of penetration of solar rays into inside space of the box through glass cover, which makes 0.55 for single glazed, 0.44 for double glazed and 0.352 for triple glazed covers,

$K$ - heat transfer coefficient of glass cover, which makes $5 \mathrm{~W} /\left(\mathrm{m}^{20} \mathrm{C}\right)$ for single glazed, $2.9 \mathrm{~W} /\left(\mathrm{m}^{20} \mathrm{C}\right)$ for double glazed and $1.1 \mathrm{~W} /\left(\mathrm{m}^{20} \mathrm{C}\right)$ for triple glazed covers,

$t_{\text {out }}$ - Outside air temperature, ${ }^{\circ} \mathrm{C}$,

$t$ - Current air temperature surrounding the air heater, ${ }^{\circ} \mathrm{C}$,

$F$ - Surface of the solar heater, $\mathrm{m}^{2}$,

$G_{v}$ - air flow through the heater, $\mathrm{kg} / \mathrm{sec}$.

Integrating the equation (4) and making simplifications with adoption the conditions $F=0 ; t=t_{\text {out }}$ the following equation is obtained: 


$$
F=\frac{G_{v} c_{\text {air }}}{K} \ln \frac{I \cdot n}{I \cdot n+K\left(t_{\text {out }}-t\right)},
$$

Substituting the values $F=b l$ and $G_{v}=b \delta \omega \rho$, In the equation (5) the main characteristics of the solar air heater is determined:

- Final temperature $t,{ }^{\circ} \mathrm{C}$ of the air at the exit of the heater in case of given length $l, \mathrm{~m}$ :

$$
t=t_{\text {out }}+\frac{I \cdot n}{K}\left(1-e^{-\frac{K l}{\delta \omega \rho_{\text {air }} c_{\text {air }}}}\right)
$$

- for determining required length $l, \mathrm{~m}$ of the heater in case of given final temperature $t$, ${ }^{\circ} \mathrm{C}$ at the exit of the heater:

$$
l=\frac{\delta \omega \rho_{\text {air }} c_{\text {air }}}{K} \ln \frac{1}{1+\frac{K\left(t_{\text {out }}-t\right)}{I \cdot n}}
$$

where: $\omega$ - velocity of the air in the heater, $\mathrm{m} / \mathrm{sec}$.

Investigation of the last equations prove that for providing high efficiency of the heater and higher temperatures of the air, it is desirable to design the heater with possible low values of height $\delta$ and velocity of the air $\omega$. It is recommended keeping the values $\delta=0.05 \mathrm{~m}$ and $\omega=0.05 \mathrm{~m} / \mathrm{s}$. However, such low values demand extremely big width $b, \mathrm{~m}$. For finding out the best conditions of operation and efficiency of the heater special computational experiments have been executed. The final temperatures $t,{ }^{\circ} \mathrm{C}$ were determined depending on various values of length $l, \mathrm{~m}$ and outside temperatures $t_{\text {out }},{ }^{\circ} \mathrm{C}$. The heater was previewed for applying in ventilation system, thus the final temperature of the air at the exit of the air heater was adopted $t=18^{\circ} \mathrm{C}$. The design outside temperature was taken $t_{\text {out }}=-19^{\circ} \mathrm{C}$, and $\delta=0,05 \mathrm{~m}, \omega=0,05 \mathrm{~m} / \mathrm{s}$. The results of calculations represented in form of a diagram shown in Fig.2.

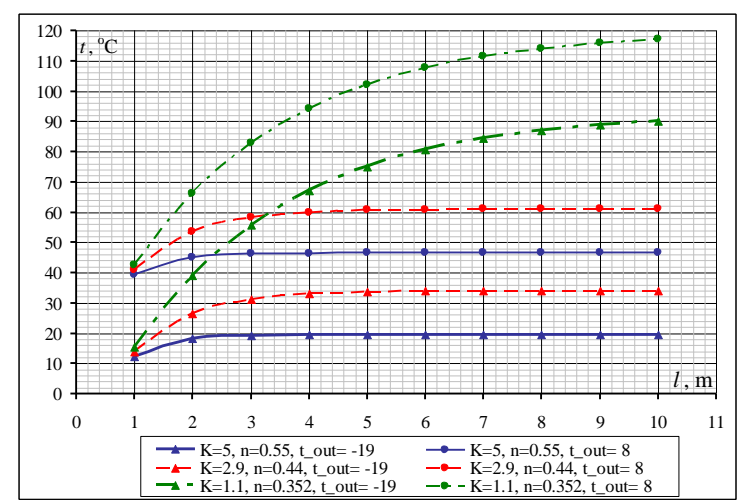

Fig.2.The final temperatures $\mathrm{t},{ }^{\circ} \mathrm{C}$ of the air in solar heaters of various lengths $l, \mathrm{~m}$ under different outside temperatures $\mathrm{t}_{\text {out }},{ }^{\circ} \mathrm{C}$. $(\delta=0,05 \mathrm{~m}, \omega=0,05 \mathrm{~m} / \mathrm{s})$.

As follows from the diagrams, the increase of the length $l$ provides higher final temperatures of the air. However, it tends to its limit and stays practically unchanged in case of lengths: $l=2 \mathrm{~m}$ for single glazed, $1=3 \mathrm{~m}$ for double glazed, and $l=8 \mathrm{~m}$ for triple glazed glass covers.

The diagrams of fig. 2 show also, that required for ventilation air temperature $t=18^{\circ} \mathrm{C}$ is provided under outside temperature $t_{\text {out }}=-19^{\circ} \mathrm{C}$ even in the $l=2 \mathrm{~m}$ long single glazed solar heater. In double and triple glazed heaters having length $l=2 \mathrm{~m}$ the ventilation air under outside temperature $t_{\text {out }}=-19^{\circ} \mathrm{C}$ is heated respectively up to $24^{\circ} \mathrm{C}$ and $40^{\circ} \mathrm{C}$, which is a good 
advantage from energy efficiency point of view. However, the higher costs of double and treble glazed heaters should be taken into account. Thus, it is becoming clear the factor of optimization of the heaters in the solar ventilation projects should be taken into account.

The diagram explains also that under higher outside temperatures $t_{\text {out }}$ the final temperatures $\mathrm{t}$ of the heated air grows. For example, under $t_{\text {out }}=8^{\circ} \mathrm{C}$ in the $2 \mathrm{~m}$ long and single glazed heater the final temperature can reach up to $45^{\circ} \mathrm{C}$, and in double and treble glazed heaters up to $52^{\circ} \mathrm{C}$ and $68^{\circ} \mathrm{C}$. This means that during most part of heating season the efficiency of the heater will be much higher.

The diagrams of fig. 2 are plotted for heaters having fixed parameters $\delta=0.05 \mathrm{~m}$ and $\omega=0.05 \mathrm{~m} / \mathrm{s}$. To evaluate the influence of those parameters on the values of final temperatures computational experiments were executed considering that the values of $\delta$ and $\omega$ are variable. The results of calculations made for single and double glazed heaters are represented in fig. $3 \mathrm{a}$ and fig. $3 \mathrm{~b}$.

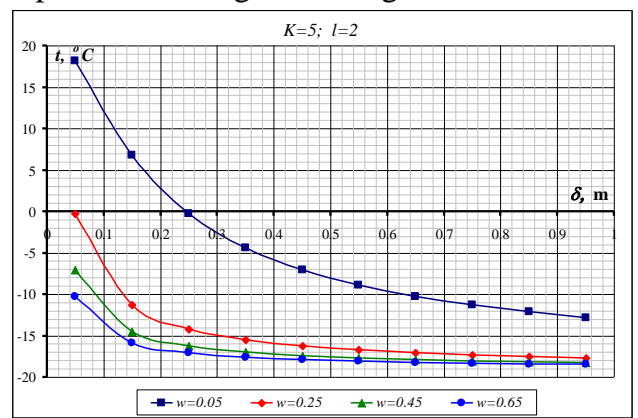

a)

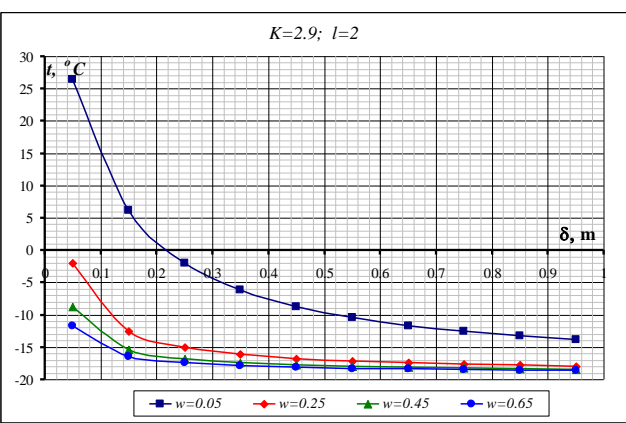

b)

Fig.3. Final temperatures of heated air in solar air heaters having different values of $\delta, \mathrm{m}$ and $\omega \mathrm{m} / \mathrm{s}$. a) single glazed heaters, b) double glazed heaters

From the diagrams is clear that the increase of $\delta$ and $\omega$ conditions growing of air flow through the heater and, therefore, the final temperatures $t$ of air decrease. Consequently, it is better choosing lower values for $\delta$ and $\omega$. In this case the width $b, m$ of the heater will increase. Therefore, the design of the heater should be made for acceptable temperature and constructive parameters.

For satisfying the stated conditions first, it is important to select the heater's technically acceptable length $l$, which should not exceed $6-8 \mathrm{~m}$. Then, the width $\mathrm{b}, \mathrm{m}$ of the heater has to be defined for given ventilation airflow using the following fraction:

$$
b=\frac{G_{v}}{\rho_{\text {air }} \delta \omega}
$$

In the last formula the value of the production $\delta \omega$ is defined by the values of outside air $\mathrm{t}_{\text {out }}$ and heated air $t$ temperatures, as well as by selected length $l, \mathrm{~m}$ of the heater. For this purpose the following formula has to be used:

$$
\delta \omega=\frac{l K}{\rho_{\text {air }} c_{\text {air }} \ln \frac{1}{1+\frac{K\left(t_{\text {out }}-t\right)}{I \cdot n}}}
$$

By substituting the obtained value of $\delta \omega$ in the equation (8) the required value of the width $b$, $\mathrm{m}$ of the heater is determined.

If the width $b, \mathrm{~m}$ of the heater exceeds the available technical facilities, then double or treble glazed heater should be selected and the same calculation has to be executed until all thermal and constructive conditions are satisfied. 
The thermal productivity of the heater can be determined by the following formula:

$$
Q=G_{v} c_{\text {air }}\left(t-t_{\text {out }}\right)
$$

\section{Example of design of a residential house with ventilation system and calculation of thermal and constructive parameters of the void type solar air heater}

For embodiment of solar ventilation, a very simple solar air heating system is suggested which is presented in fig. 4

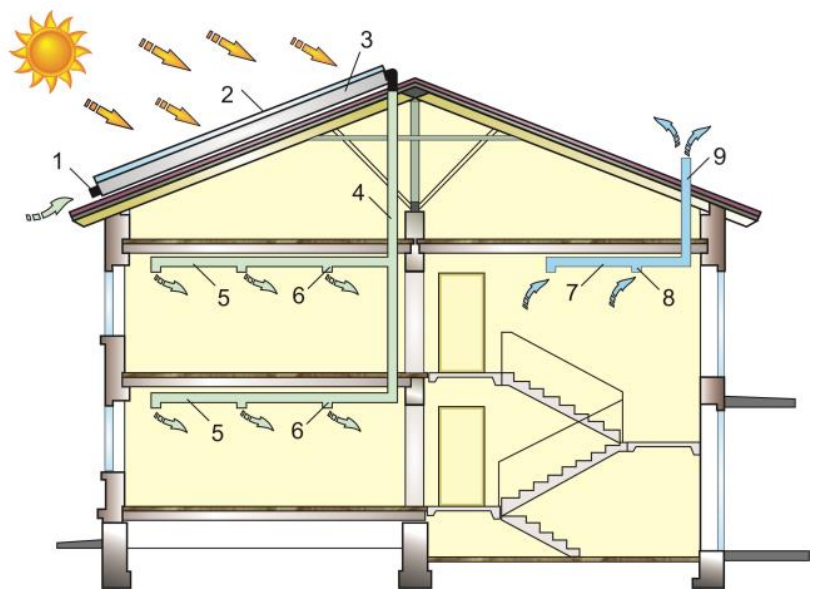

Fig.4. Solar ventilation system's principle scheme.

1-outside air inlet tube, 2-sollar air heater's glass cover, 3- solar air heater, 4- hot air plenum vertical duct, 5- hot air distributing horizontal duct, 6- ventilation air plenum grills, 7- inside used air exhaust horizontal duct, 8-inside air exhaust grills, 9-inside used air evacuation pipeline

The system operates in the following way: the outside fresh air is taken through intake unit with air filter (1) passes through the air heating solar collector (2), where is heated up to temperature $t_{v . i n},{ }^{\circ} \mathrm{C}$ and by the air circulating fan is blown into the air distribution ductwork (4). The warm air enters into rooms through inlet openings (6), inside polluted air is exhausted from rooms by exhausting duct (9) through inside air outlet openings (8).

Based on developed method a solar ventilation system equipped with void type solar heater was designed for 50 habitant's family house. The required inside temperature in the house is $t_{i n}=21^{\circ} \mathrm{C}$. Technically possible length for installing the solar heater on the southern slope of the roof is $l=5 \mathrm{~m}$.

The house is located in Yerevan city having the following climatic parameters:

1 - Outside design temperature $-t_{\text {out }}=-19^{\circ} \mathrm{C}$,

2- Required temperature of the ventilation air at the exit of solar heater $-t_{i n . v}=21^{\circ} \mathrm{C}$,

3 -Solar radiation daily average intensity on the south facing orientation $-I=350 \mathrm{~W} / \mathrm{m}^{2}$,

1. Quantity of ventilation outside fresh airflow $G_{v}, \mathrm{~kg} / \mathrm{s}$.

$$
G_{v}=\frac{20}{3600} n \rho_{\text {air }}=\frac{20 \cdot 7 \cdot 1,25}{3600}=0.0486 \mathrm{~kg} / \mathrm{s} \text {. }
$$

2. By the formula (9) is calculated the value of $\delta \omega$ and the appropriate glazing rate of the solar air heater is defined: 


$$
\delta \omega=\frac{\text { for single glazed heater, having } \mathrm{K}=5 \mathrm{~W} /\left(\mathrm{m}^{20} \mathrm{C}\right) \text { and } \mathrm{n}=0.55}{1.25 \cdot 1000 \ln \frac{1}{1+\frac{5((-19)-21)}{350 \cdot 0.55}}} \text { cannot be identified as the value under the "log" sign }
$$

is negative.

This means that single glazed heater cannot provide heating of outside air up to required $t_{i n . v}=21^{\circ} \mathrm{C}$ temperature. Therefore, double glazed air heater with $K=2.9 \mathrm{~W} /\left(\mathrm{m}^{2 \circ} \mathrm{C}\right), n=0.44$

$$
\text { and } \delta \omega=\frac{5 \cdot 2 \text {. }}{1.25 \cdot 1000 \ln \frac{1}{1+\frac{2.9((-19)-21)}{350 \cdot 0.44}}}=0.0083 \text { should be chosen. }
$$

This means that double glazed heater can provide heating of outside air up to required temperature $t_{i n . v}=21^{\circ} \mathrm{C}$. For this reason, a double glazed heater is selected.

3. By the formula (8) the width $b, m$ of the heater is defined for given ventilation air flow $G_{v}=0.0486 \mathrm{~kg} / \mathrm{s}$; $b=\frac{0.0486}{1.25 \cdot 0.0083}=4.7 \mathrm{~m}$,

4. The height $\delta, \mathrm{m}$ of the heater is determined by the following fraction keeping the value of the air velocity $\omega=0.5 \mathrm{~m} / \mathrm{s} .: \delta=0.0083 / \omega=0.0083 / 0.5=0.017 \mathrm{~m}$.

Therefore, the constructive parameters of the solar heater are the followings: length $l=5 \mathrm{~m}$, width $-b=4.7 \mathrm{~m}$, height $-\delta=0.017 \mathrm{~m}$. The same air flow can be provided assuming $\omega=0.25 \mathrm{~m} / \mathrm{s}$., then the height of the heater can be chosen $\delta=0.034 \mathrm{~m}$

Average daily thermal capacity of the heater makes:

$$
Q=0.0486 \cdot 1000(21-(-19))=1945 \mathrm{~W} \text {. }
$$

\section{Conclusion}

The suggested construction of solar ventilation system and method for its calculation allow developing, designing and implementing high efficiency ventilation system in residential houses and saving large quantities of fuel.

\section{References}

1. Melikyan, Z. A.: Heating-Cooling of Buildings. Efficiency of Conventional and Renewable Technologies. LAP Lambert Academic Publishing, Germany (2012) ISBN978-3-8443-1939-2.

2. Zohrab Melikyan, Siranush Egnatosyan. Developing of New Structure of Flat Plate Solar Water Heater and Method for Calculation and Design. International Journal of Energy and Power Engineering. Vol. 5, No. 4, 2016, pp. 141-147. doi: 10.11648/j.ijepe.20160504.11

3. C. Binggeli, Building systems for interior designers. Published by John Wiley \& Sons, Inc., Hoboken, New Jersey , 469, (2003) ISBN 0-471-41733-5

4. M.G.Davies, Building heat transfer. Published by John Wiley \& Sons Ltd, The Atrium, Southern Gate, Chichester, 512, (2004) ISBN 0-470-84731-X

5. J. P. Rafferty, Climate and climate change. Britannica Educational Publishing, 367, (2011) ISBN 978-1-61530-388-5

6. Volkow, A.I., Jarskij, A.M., 2005. Chemical Large Guide. Publishing house "Soviet school", Moscow, 608 . 
7. K.E.Heselton, Boiler operator's handbook. Published by Fairmont Press, Inc., 413, (2005) ISBN 0-88173-434-9

8. F.Porges, HVAC Engineer's Handbook, Eleventh edition, Printed and bound in Great Britain by MPG Books Ltd., Bodmin, Corn wall (2001) ISBN 0750646063

9. ASHRAE 62. ANSI/ASHRAE standard 62-2001. Ventilation for acceptable indoor air quality. American Society of Heating Refrigerating and Air Conditioning Engineers. Atlanta. (2001)

10. Bluyssen P., Seppänen O., Fernandes E., Clausen G., Müller B., Molina J., Roulet CA. (2001) AIRLESS: A European project to optimize Indoor Air Quality and Energy consumption of HVAC systems.In: Proceedings of CLIMA 2000. Naples.

11. ASHRAE Handbook Fundamentals - CHAPTER 28 - Combustion and fuels. (2013)

12. Hans Dieter Baehr, Karl Stephan, "Heat and Mass Transfer," Third revised edition, Springer-Verlag Berlin Heidelberg, (2011), 762, ISBN 978-3-642-20020-5.

13. M. A. Mikheev, I. M. Mikheeva, "Heat transfer fundamentals," Second edition, Publ. House: "Energia", Moscow, (1977), 344, Published in Russian.

14. "Air Properties-Temperature, density, specific heat, thermal conductivity, expansion coefficient, kinematic viscosity and Prandtl's number" http://www.engineeringtoolbox.com/airproperties-d_156.html

15.Zohrab Melikyan, Vahan Nranyan. Solar Water Heaters: Cylindrical Shell and Tube Type. Encyclopedia of Energy Engineering and Technology, Second Edition. Taylor and Francis: New York, Published online: 17 Jun 2015; 1760-1767pp.

16. Zohrab Melikyan. Energy Efficiency and Cost Effectiveness of Solar Water Heaters. International Journal of Energy and Power Engineering. Vol. 4, No. 3, 2015, pp. 184188. doi:10.11648/j.ijepe.20150403.17.

17. H. P. Garg Treatise on Solar Energy, Volume 1: Fundamentals of Solar Energy/New York, Toronto, 1982, John Villy and Sons Ltd, p. 587, ISBN 10180 X.

18. "Constructive climatology," Constructions Codes of Armenia II-7.01-2011, Yerevan, 2013, 54 pages, Published in Armenian.

19. Construction Norms RACN 24-01-2016 "Thermal Protection of Buildings", 63 pages ISBN 978-9939-1-0421-8

20. V. N. Bogoslovskij, "Thermal physics of constructions," Publ. house "High School", Moscow, 1982, 415 pages, Published in Russian.

21. Engineering ToolBox, (2003). Building Area per Person. [online] Available at: https://www.engineeringtoolbox.com/number-persons-buildings-d_118.html 